\title{
The Farm as a Thermodynamic System: Implications of the Maximum Power Principle
}

\author{
Carl F. Jordan ${ }^{1}$
}

Received: 2 June 2016/Accepted: 19 August 2016/Published online: 15 September 2016

(C) Springer International Publishing Switzerland 2016

\begin{abstract}
A farm can be considered a thermodynamic system that uses exosomatic energy (fertilizers and pesticides) to facilitate crop yield derived from endosomatic (photosynthetically derived) energy. Because farms are thermodynamic systems, they are subject to the Maximum Power Principle. This means that farmers can maximize yield to increase economic competitiveness or maximize exosomatic energy use efficiency to minimize pollution, but they cannot do both at the same time. To maintain competitiveness, farmers usually choose to maximize yield, a decision that often results in degradation of the environmental commons. Farms are self-organizing systems in that yield is converted to dollars, some of which the farmer uses to manage cropping systems embedded in the farming system. If management of an industrial cropping system is modified to use nature's services, energy use efficiency of the farm increases and pollution is reduced.
\end{abstract}

Keywords Maximum Power Principle - Energy use efficiency $\cdot$ Industrial agriculture $\cdot$ Sustainable agriculture $\cdot$ Services of nature

\section{Introduction: the Course of Agricultural Development}

The course of agricultural development is the history of human struggle to conquer nature, to bend nature to the economic demands of society (Jordan 2013).

Carl F. Jordan

carljordanecology@gmail.com

1 Odum School of Ecology, University of Georgia, Athens, GA, USA

\section{The Agricultural Revolution}

Before the nineteenth century, slaves, hired hands, and draft animals were the only energy subsidies available to help farmers wrest food from the earth, and fields were cultivated with stick-like plows that opened a furrow by scratching the soil surface. Changes began with the emergence of the Industrial Revolution in the 1800s. Invention of the moldboard plow allowed farmers to turn the earth more efficiently. Utilization of steam-powered tractors to pull the plows enabled farmers to cultivate their fields more effectively. These innovations increased the intensity of energy utilization and resulted in greater agricultural productivity. This in turn allowed greater occupational diversity and enabled expansion of cities.

\section{The Green Revolution}

The Green Revolution refers to a series of research, development, and technology transfer activities that occurred in the decades after WWII and resulted in dramatic increases of agricultural production. The techniques are often referred to as "industrial agriculture." Advances included new, high-yielding varieties of cereals, chemical fertilizers, pesticides, controlled water supply, and more powerful machinery. Petroleum became the primary source of energy that propelled the expansion of yield. All of these together were seen as a package of practices to supersede traditional technology and to be adopted as a whole. In the early days of the Green Revolution, biological and agricultural scientists saw an enormous potential. They were fired with enthusiasm and faith, excited at the way in which the new varieties responded to increased subsidies. The spectacular increases of wheat production during the 1960s encouraged this optimism. As the Green Revolution spread 
to other crops, it was hailed as the key to banishing world hunger.

\section{Problems of Industrial Agriculture}

The publication by Rachel Carson of Silent Spring (Carson 1962) was a wake-up call concerning the environmental downside of energy-intensive agriculture. Despite initial denial of Carson's claims by agroindustry, evidence gradually emerged showing that there really were ecological as well as economic and social problems associated with industrial agriculture. Over the years, researchers have documented many of these problems:

- Industrial agriculture is highly dependent upon petroleum to synthesize fertilizers, pesticides, and herbicides, and to fuel the airplanes, trucks, and tractors that deliver and spread these compounds. Because petroleum supply is erratic (Kerr 2008), prices for commodities are uncertain and profits for farmers fluctuate broadly depending on economic cycles.

- Use of genetically modified crops can put the farmer under control of international corporations that own patents on the crops. As use of these crops spreads, the world's food supply becomes increasingly dependent on the economic goals of a handful of corporations and not on the needs and desires of consumers (Then 2000).

- The simple, vertically integrated economic food chains common in industrial agriculture can be highly susceptible to economic and political disturbances (Striffler 2005).

- Factory farms have adverse effects on rural communities, such as deteriorating socioeconomic conditions and loosening of community social fabric (Lobao and Stofferhan 2007).

- Industrial agriculture is leading to a depletion of water resources. Groundwater level in Ogallala Aquifer that supplies irrigation water to the High Plains of the USA has dropped 150 feet or more, forcing many farmers to abandon their wells (Little 2009).

- Prevalence of monocultures in industrial food production systems leads to loss of genetic diversity (Soule and Piper 1992). Low genetic diversity increases the risk of disease or insect outbreak (Real 1996).

- Inorganic nitrogen leached from fertilizers spread on agricultural fields enters waterways and causes hypoxia. "Within and near oxygen-depleted waters, finfish and mobile macroinvertebrates experience negative effects that range from mortality to altered trophic interactions" (Breitburg et al. 2009).

- Nitrate leached into water supplies can interfere with the ability of blood to carry oxygen to vital tissues of the body in infants 6 months old or younger. The resulting illness is called methemoglobinemia or "blue baby syndrome" (Department of Environmental Quality 2016).

- Nitrogen volatilized from fertilizers enters the troposphere and poses direct health threats to humans and causes substantial losses of agricultural production (Galloway et al. 2008).

- Animal waste lagoons and spray fields near aquatic environments can significantly degrade water quality and endanger health (Mallin 2000).

- Overuse of antibiotics in the livestock industry has resulted in increasing resistance of pathogens (Mlot 2000).

- Increasing resistance of weeds to a single type of herbicide is resulting in the need for an expensive series of herbicides (Service 2007).

- Use of insecticides kills beneficial insects that can help control pest species (Soule and Piper 1992).

- Plowing and other methods of tillage that disrupt the structure of the soil result in erosion that destroys croplands (McNeill and Winiwarter 2004).

\section{Intractability of Agricultural Problems}

Although there now is overwhelming scientific evidence for the environmental problems of agriculture and methods have been recommended to alleviate them (Fresco 2016), the problems have continued despite the economic, social, and environmental costs incurred on society (EPA 2015a). The question is "Why?" Why are the environmental problems of agriculture so intractable? The goal of industrial agriculture is to maximize yield, and increasing yield requires intensifying the use of energy subsidies such as fertilizers, pesticides, irrigation, and petroleum-fueled machinery. It is the intensification to increase yield combined with inefficiency resulting from intensification that causes environmental problems to be intractable. To understand why this inefficiency occurs, it is necessary to think of a farm as a thermodynamic system having energy inputs and outputs. The Maximum Power Principle (Odum and Pinkerton 1955) derives a proof that energy use efficiency of thermodynamic systems varies as a function of energy input into these systems, and efficiency at maximum power output is always less than the maximum efficiency possible. Maximizing rate of output (yield) of a system and maximizing its energy efficiency are incompatible goals.

\section{Objectives}

The objectives of this paper are: 
- To show that a farm as a thermodynamic system is subject to the Maximum Power Principle and that this principle can explain why agricultural problems have been so intractable.

- To show how management that increases endosomatic (photosynthetically derived) feedback in agricultural systems can increase exosomatic (industrially derived) energy use efficiency and decrease environmental pollution.

\section{The Maximum Power Principle}

A "law of maximum energy" for biological systems (Lotka 1922a) asserts that the most important thing for the survival of biological organisms is a large energetic output in the form of growth, reproduction, and maintenance. Organisms with a high output relative to their size should win out in the competitive struggle for existence. Building on this "fourth law of thermodynamics" (Lotka 1922b), Odum and Pinkerton (1955) proposed a Maximum Power Principle. It states that non-equilibrium (entropy generating) thermodynamic systems operate at an energy use efficiency that is optimum for maximum power output, an efficiency that is always less than for maximum efficiency.

\section{The Farm as an Autocatalytic, Thermodynamic System}

A farm is an autocatalytic (self-organizing), thermodynamic system that converts photosynthetic energy to energy in the form of crop yield. It uses energy subsidies (diesel fuel, industrial fertilizer, pesticides) to reduce entropy, that is, prevent degradation of the cropland into disorder. Without these energy inputs, successional species (weeds) would displace crop species (Schneider and Kay 1994). Money from the sale of yield provides feedback that stimulates further input of fuel, nitrogen, etc., and is a catalyst that maintains cropland as an improbable ecological community (Allen et al. 2003). If energy subsidies are depleted more rapidly than they are replenished, the system disintegrates. In the words of Odum (1995), "When the energy concentration of a source is below the critical minimum value required to sustain structure against its normal rate of depreciation, the autocatalytic system changes back to a simple linear energy diffusion dispersal. Autocatalysis stops."

\section{Energy Analysis for Farming Systems}

In a thermodynamic analysis of farming systems, input energy consists of direct solar energy (photosynthesis), indirect solar energy (rainfall), stored solar energy (soil organic matter), and energy subsidies such as fertilizers, pesticides, and fuel that facilitate the conversion of solar energy to crop yield by maintaining structure of the cropland. Output energy is equivalent to the energy released by oxidation of the crop yield.

\section{Types of Conversions (Giampietro 2004)}

- "Exosomatic energy" sometimes called an energy subsidy (Odum et al. 1979) specifies energy conversions in the farming system using sources of power external to the system. Exosomatic energy conversions in resource management systems come about using the potential energy of tractor fuel, the kinetic energy of labor, or the energy embodied in fertilizers, pesticides, and herbicides (Odum and Odum 1981). The energy embodied in nitrogen fertilizer, for example, is equal to the amount of energy required by the Haber-Bosch process to synthesize ammonia from atmospheric nitrogen. The energy embodied in phosphate fertilizer is the energy required to mine phosphate-bearing rock and extract it using industrial processes.

- "Endosomatic energy" indicates energy conversions linked to physiological processes in the soil-crop system. In addition to photosynthetic energy from sunlight, endosomatic energy includes "services of nature" that are ultimately fueled by photosynthesis within the farming system. An example is nutrient recycling by the microbial soil communities that gain their energy from soil organic matter (reduced carbon) derived from decaying parts of plants and animals (Jordan 2013). Other services of nature and their underlying mechanisms are given in Table 1.

\section{Output/Input Ratios}

An output/input ratio can be used to determine the efficiency of a production system. In modern economic systems, money-out/money-in is the ratio that determines the short-term efficiency of a particular system or investment, but it does not adequately consider pollution and resource degradation caused by the production system. In an economy governed by biophysical laws, energy-out/exosomatic energy-in is the critical ratio. It takes into account the longterm impact on biophysical systems resulting from extraction of resources by the production system and the impact of inputs into the biophysical system from pollution created by the production system (Giampietro 1997). The higher the ratio, the more efficient the system and the lower the environmental impact. Murphy and Hall (2010) have called the energy-out/energy-in ratio "EROI" or energy returned on energy invested. There have been many studies 
Table 1 Services of nature in sustainable agricultural systems (Daily et al. 1997; Jordan 2013)

\begin{tabular}{|c|c|}
\hline Service of nature & Mechanism \\
\hline Purification of air and water & Filtration of water by soil organic matter, filtration of air by leaves \\
\hline Mitigation of droughts and floods & Storage of water in soil made permeable by roots and the community of soil organisms \\
\hline $\begin{array}{l}\text { Detoxification and decomposition of } \\
\text { wastes }\end{array}$ & Metabolized by soil bacteria \\
\hline Soil formation & $\mathrm{CO}_{2}$ respired by soil organisms reacts with $\mathrm{H}_{2} \mathrm{O}$ to form carbonic acid that decomposes bedrock \\
\hline Pollination of Crops & Beneficial insects \\
\hline Dispersal of seeds & Birds, insects, wind \\
\hline $\begin{array}{l}\text { Conservation and recycling of } \\
\text { nutrients }\end{array}$ & Community of microorganisms in the soil \\
\hline Phosphorus mobilization & Organic acids secreted by certain crop plants \\
\hline Facilitate nutrient uptake & Mycorrhizal fungi \\
\hline Nitrogen fixation & Bacteria symbiotic with leguminous plants \\
\hline Pest control & Beneficial insects \\
\hline Disease mitigation & $\begin{array}{l}\text { Spatial and temporal species/genetic diversity that increases energy burden on pest and disease } \\
\text { organisms }\end{array}$ \\
\hline Over-yielding & Positive interactions between plants through intercropping \\
\hline Increased efficiency of resource use & $\begin{array}{l}\text { Niche separation (structural diversity as in agroforestry) ensures energy not used by one species is used } \\
\text { by another }\end{array}$ \\
\hline
\end{tabular}

to determine the efficiency with which exosomatic energy in the form of fertilizers, pesticides, and fuel is used to produce food under different management and environmental conditions (Black 1971; Steinhart and Steinhart 1974; Cox and Atkins 1979; Fluck and Baird 1980; Pimentel and Pimentel 2008; Gelfand et al. 2010). Although the quality of energy returned is of a different quality than the energy invested, the ratios are useful in that they have illuminated important concepts. For example, the efficiency of exosomatic energy to produce grass fed beef is higher than that for grain fed beef; thus, grass fed beef is less environmentally polluting.

The problem with published values of energy use efficiency to evaluate production systems is that the values are good only for a particular rate of energy input. The Maximum Power Principle specifies that the ratios for maximum energy efficiency and for maximum power output occur at different rates of input. To understand how this differential has caused the intractability of agricultural pollution, power output (yield) must be determined over a range of energy inputs. This can be done theoretically through the use of the classical economic production function.

\section{Production Functions in Agriculture}

Before developing a theoretical energy production function for a farm, it is useful to review how production functions are used in agriculture.

\section{Agricultural Production Functions}

Agricultural production functions relate quantity of yield in terms of mass or volume to a range of input subsidies. The black line curve in Fig. 1 represents output in terms of kilograms of corn produced per hectare per year as a function of input of nitrogen fertilizer applied per hectare per year for a particular set of conditions (Deberton 2012). The dots on the curve represent the values in Table 2, column 3 , the efficiency with which nitrogen fertilizer produces corn at each input rate. As input increases from zero, the efficiency of nitrogen to produce corn increases until the inflection point of the curve where it changes from convex to concave. The point is determined by a line drawn from the base to where it is tangent to the curve. The efficiency at this point is 52.7 . That means that $112 \mathrm{~kg} / \mathrm{ha}$ of nitrogen on this farm will yield $5900 \mathrm{~kg}$ corn/ha. With greater nitrogen inputs, efficiency decreases, but yield still increases. Efficiency as a function of input rate is graphed in Fig. 2.

Columns 1-2 in Table 2 are from Deberton (2012). Column 1 represents the independent variable $(x)$, the rate of nitrogen added to a field of corn in kilograms per hectare. Column 2 is the dependent variable $(y)$, the yield of corn in kilograms per hectare at various levels of nitrogen input. Column 3 is the average efficiency ratio (output/ input ratio).

Column 4 represents the efficiency at each level of input as a percentage of efficiency where average efficiency factor is maximum. It is assumed that at this point (52.7), $100 \%$ of the input is used for corn and none is lost as 
Fig. 1 Output of corn in $\mathrm{kg} / \mathrm{ha}$ (black line) per year as a function of nitrogen input in $\mathrm{kg} /$ ha; income (green line) and environmental costs (red line) as a function of nitrogen input

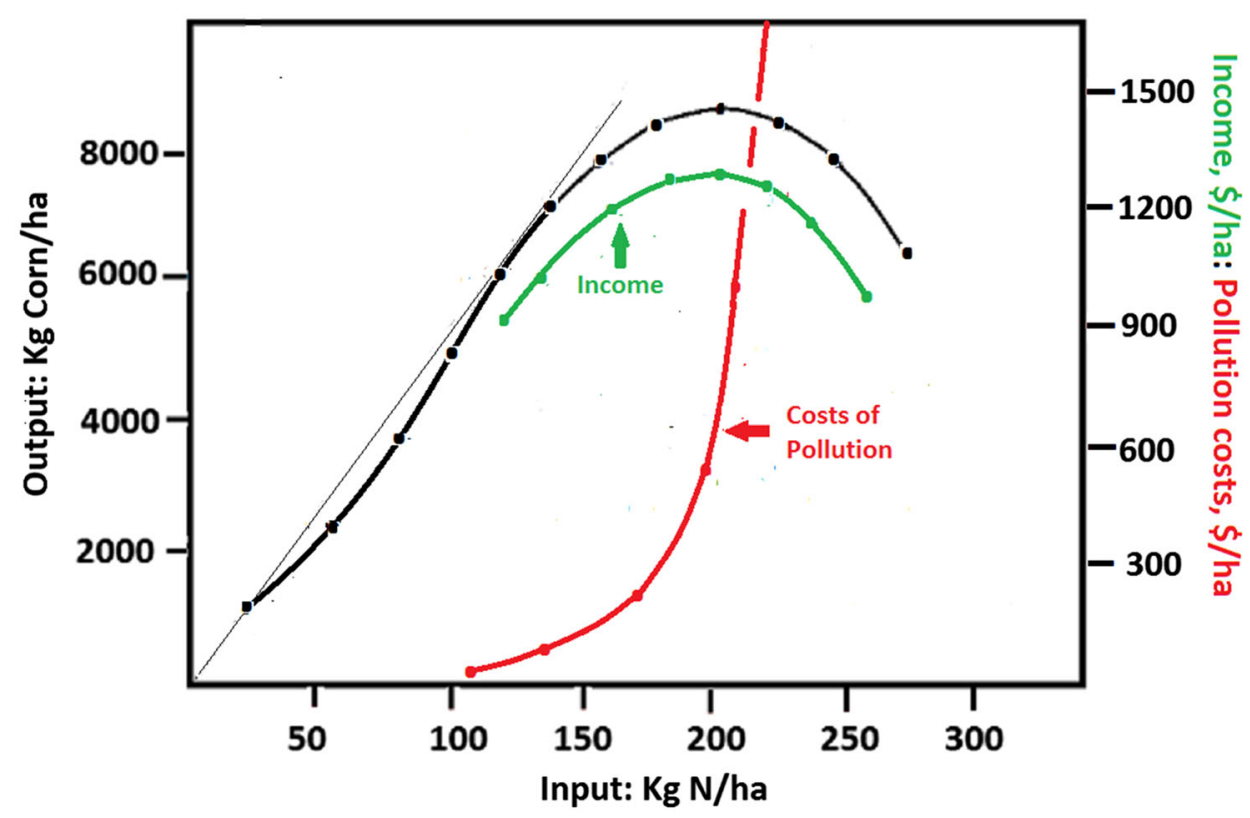

Table 2 Database for Fig. 1

\begin{tabular}{|c|c|c|c|c|c|}
\hline $\begin{array}{l}1 \mathrm{~N} \text { added } \\
{[\mathrm{kg} / \mathrm{ha}(x \text { axis })]}\end{array}$ & $\begin{array}{l}2 \text { Total yield } \\
{[\mathrm{kg} / \mathrm{ha}(y \text { axis })]}\end{array}$ & $\begin{array}{l}3 \text { Average } \\
\text { efficiency factor }(y / x)\end{array}$ & $\begin{array}{l}4 \% \text { of maximum } \\
\text { efficiency factor }\end{array}$ & $\begin{array}{l}5 \mathrm{~kg} / \mathrm{ha} \mathrm{N} \\
\text { utilized }\end{array}$ & $\begin{array}{l}6 \mathrm{~kg} / \mathrm{ha} \mathrm{N} \\
\text { pollution }\end{array}$ \\
\hline 0 & 0 & & & & \\
\hline 22.4 & 1029 & 45.9 & & & \\
\hline 44.8 & 2209 & 49.3 & & & \\
\hline 67.2 & 3458 & 51.5 & & & \\
\hline 89.6 & 4714 & 52.6 & & & \\
\hline $112.0^{\mathrm{a}}$ & 5900 & 52.7 & 100 & 112.0 & 0 \\
\hline 134.4 & 6948 & 51.7 & 98 & 131.7 & 2.7 \\
\hline 156.8 & 7796 & 49.7 & 94 & 147.4 & 9.4 \\
\hline 179.2 & 8367 & 46.7 & 89 & 159.5 & 19.7 \\
\hline $201.6^{\mathrm{b}}$ & 8593 & 42.6 & 81 & 163.3 & 38.3 \\
\hline 224.0 & 8411 & 37.5 & 71 & 159.0 & 65.0 \\
\hline 246.4 & 7739 & 31.4 & 60 & 147.8 & 98.6 \\
\hline 268.8 & 6521 & 24.2 & 46 & 124.6 & 144.2 \\
\hline
\end{tabular}

${ }^{a}$ Input at maximum nitrogen use efficiency

b Input for maximum total yield

pollution. The percentage of maximm efficiency from column 4 times the quantity of nitrogen added from column 1 represents the amount of nitrogen taken up in the production of corn (column 5). Column 6 is the nitrogen going to pollution, calculated by column 1 minus column 5 . For example, at the point of maximum yield, $38.3 \mathrm{~kg}$ of nitrogen fertilizer is lost as nitrate to the groundwater or is volatilized.

\section{Choosing the Economically Optimum Rate of Nitrogen Input}

To determine how income and pollution costs respond to different rates of nitrogen input (Table 3), we begin with the nitrogen and yield values from Table 2. Then, we select one set of values out of the many possible for price of corn and for cost of pollution control and use them to calculate 
Fig. 2 Nitrogen use efficiency as a function of rate of nitrogen input, from column 3, Table 2

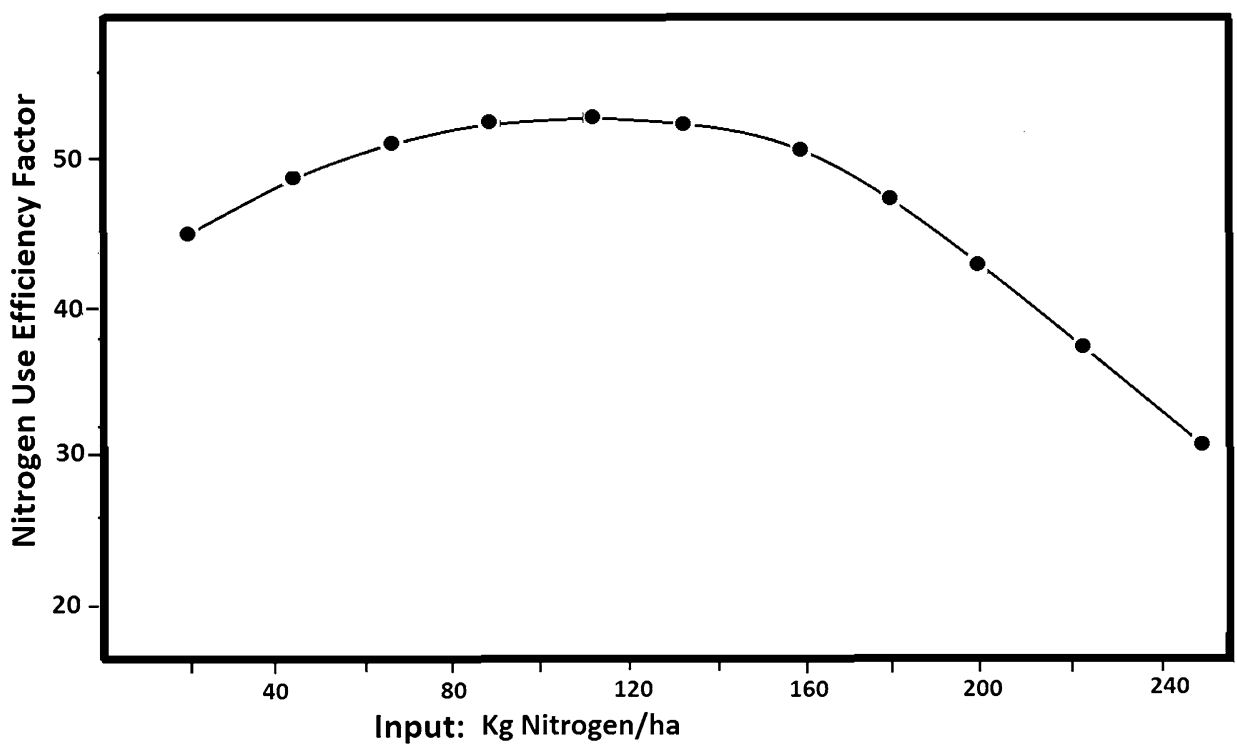

Table 3 Calculation of gross income, cost of pollution, and income if pollution costs were paid by farmer

\begin{tabular}{llllll}
\hline $\begin{array}{l}1 \mathrm{~N} \text { added }(\mathrm{kg} / \\
\text { ha) }\end{array}$ & $\begin{array}{l}\text { 2 Yield (kg corn/ } \\
\text { ha) }\end{array}$ & $\begin{array}{l}\text { 3 Gross income }(\$ / \\
\text { ha) }\end{array}$ & $\begin{array}{l}4 \mathrm{~kg} / \mathrm{ha}, \mathrm{N} \\
\text { pollution }\end{array}$ & $\begin{array}{l}\text { 5 Cost/ha, N } \\
\text { pollution }^{\text {b }}\end{array}$ & $\begin{array}{l}\text { 6 Gross income minus environmental } \\
\text { costs }^{\mathrm{a}}\end{array}$ \\
\hline 112.0 & 5900 & $\$ 929.00$ & 0 & 0 & $\$ 929.00$ \\
$134.4^{\mathrm{d}}$ & 6948 & $\$ 1094.17$ & 2.7 & $\$ 71.44$ & $\$ 1022.73$ \\
156.8 & 7796 & $\$ 1227.72$ & 9.4 & $\$ 248.72$ & $\$ 970.00$ \\
179.2 & 8367 & $\$ 1317.63$ & 19.7 & $\$ 521.56$ & $\$ 796.07$ \\
$201.6^{\text {c }}$ & 8593 & $\$ 1353.23$ & 38.3 & $\$ 1013.42$ & $\$ 339.81$ \\
224.0 & 8411 & $\$ 1324.57$ & 65.0 & $\$ 1719.90$ & $\$-395.33$ \\
246.4 & 7739 & $\$ 1218.74$ & 98.6 & $\$ 2608.96$ & $\$-1390.22$ \\
268.8 & 6521 & $\$ 1026.93$ & 144.2 & $\$ 3815.53$ & $\$-2786.60$
\end{tabular}

${ }^{a}$ Income if famer had to pay the cost of pollution

${ }^{\mathrm{b}}$ Cost to the environmental commons

c Maximum yield, conventional corn

${ }^{\mathrm{d}}$ Optimum compromise between economics and environmental protection

gross income (green line, Fig. 1), amount of pollution for each rate of nitrogen input, environmental cost per hectare for each level of input (red line, Fig. 1), and the income to farmer if he had to pay the costs of pollution.

Columns 1, 2, and 4 in Table 3 are from Table 2. Column 3 is the gross income to the farmer if the price of corn in the USA is $\$ 4.00$ per bushel and there is $25.4 \mathrm{~kg}$ of corn per bushel. The costs of nitrogen pollution from agriculture that causes hypoxia in the Gulf of Mexico are difficult to calculate because the damage is diffuse. For column 5, we use the cost of removing nitrate from drinking water as a proxy (see Table 4). Column 6 is column 3 minus column 5. Column 6 would be the farmer's income, if he had to pay for the costs of environmental pollution. The economically optimum rate of nitrogen input for a farmer would be $201.6 \mathrm{~kg} / \mathrm{ha}$, while the optimum compromise between economics and environmental protection would be $134.4 \mathrm{~kg} / \mathrm{ha}$. Regardless of the price of corn and the cost of environmental cleanup, the economically optimum rate of nitrogen input into the system for the farmer as a businessman is that which produces maximum yield. The optimum compromise between income for farmer and pollution abatement is where the difference between gross income minus environmental cost is greatest.

The cost associated with removing nitrate from drinking water may not be the most appropriate way to calculate costs. Mitcsh et al. (2001) proposed using wetlands as an efficient way to remove nitrate from agricultural runoff. When nitrate-nitrogen is introduced to wetlands through small streams or tile drains, anaerobic microbes carry out high rates of denitrification. Costs of establishing wetlands vary greatly, from about $\$ 44,460 /$ ha to $\$ 214,890 /$ ha (Baca 
Table 4 Calculation of the cost of removing nitrate nitrogen from contaminated water

Cost of removing nitrate from drinking water varies between one and two dollars per thousand gallons or $3785 \mathrm{~L}$ (Jensen et al. 2012)

The maximum contaminant level (MCL) in drinking water as $\mathrm{NO}_{3}-\mathrm{N}$ is $10 \mathrm{mg} / \mathrm{L}$. The $\mathrm{MCL}$ is the highest level of $\mathrm{NO}_{3}-\mathrm{N}$ that is allowable in public drinking water supplies by the US Environmental Protection Agency (EPA 2015b)

If there are $.010 \mathrm{~g} \mathrm{NO}_{3}-\mathrm{N} / \mathrm{L}$, then there are $37.8 \mathrm{~g}$ in $3785 \mathrm{~L}$

If it costs $\$ 1.00$ to remove the $\mathrm{NO}_{3}-\mathrm{N} / \mathrm{L}$ in $37.8 \mathrm{~L}$, the cost per $\mathrm{kg}$ is $\$ 26.46$

At the input rate of nitrogen for maximum yield (201.6 kg/ha), N pollution is $38.3 \mathrm{~kg} / \mathrm{ha}$. Cost then is $\$ 1013.42 / \mathrm{ha}$

et al. 2016; Colorado State 2016). Assuming a wetland will last for 100 years before eutrophication ends its function, amortized costs would amount to $\$ 444-\$ 2148$ per year, figures that bracket the estimated costs of nitrate removal by industrial processes.

\section{An Energy Production Function for Agriculture}

Agricultural production functions demonstrate yield as a function of one particular type of input. To show how a farm is governed by the Maximum Power Principle, an energy production function is needed that demonstrates energy out (yield) as a function of all exosomatic energy inputs (Fig. 3).

The black line in Fig. 3 is a theoretical energy production function for corn monocultures in the USA. As in all biological production systems, the function is sigmoid (Smathers et al. 1983), and maximum energy use efficiency always occurs at an input that is lower than that for maximum yield as specified by the Maximum Power Principle. The black line (scales on the left) indicates both biomass of corn yield and the energy embodied in corn yield as a function of the sum of all exosomatic energy subsidies into the system. The green line (scale on the right) is the income from sale of the corn as a function of energy input. The red line (scale on the right) is the environmental cost of energy pollution as a function of energy input.

Energy input at point $B$ is $8.115 \times 10^{6} \mathrm{kcal} / \mathrm{ha}$, and output in the form of corn is $31.158 \times 10^{6} \mathrm{kcal} / \mathrm{ha}$ or $8655 \mathrm{~kg} / \mathrm{ha}$ (data from Pimentel and Pimentel 2008). These data are representative of average corn monocultures in the USA, and we assume that the average industrial corn farmer in the USA manages for maximum yield. The energy use efficiency ratio for subsidies at this point is 3.84 (energy output/energy input).

A line drawn from the base of the graph is tangent to the production function at point $\mathrm{A}$. This is where the maximum energy use efficiency (the energy-out/energy-in ratio or EROI) is highest. Data for point A are from de Ponti et al.'s (2012) review of low-input agriculture. They analyzed 362 published organic-conventional comparative crop yields and found that low input (organic) yields averaged $80 \%$ of conventional yields. Eighty percentage of yield at point B is $24.93 \times 10^{6}$ $\mathrm{kcal} / \mathrm{ha}$. Pimentel (2006) compared inputs from low-input
Fig. 3 Energy output, yield, income for farmer, and costs of pollution per hectare as a function of exosomatic energy input (energy subsidy) into an energy-intensive corn production system. $A$ indicates the point where energy use efficiency (energy output/ energy input) is highest. $B$ indicates the point of maximum yield. The absolute values for farmer income and environmental costs will vary on a case-by-case basis, but as input increases beyond point $A$, environmental costs will always be concave upward, while farmer income will always be concave downward

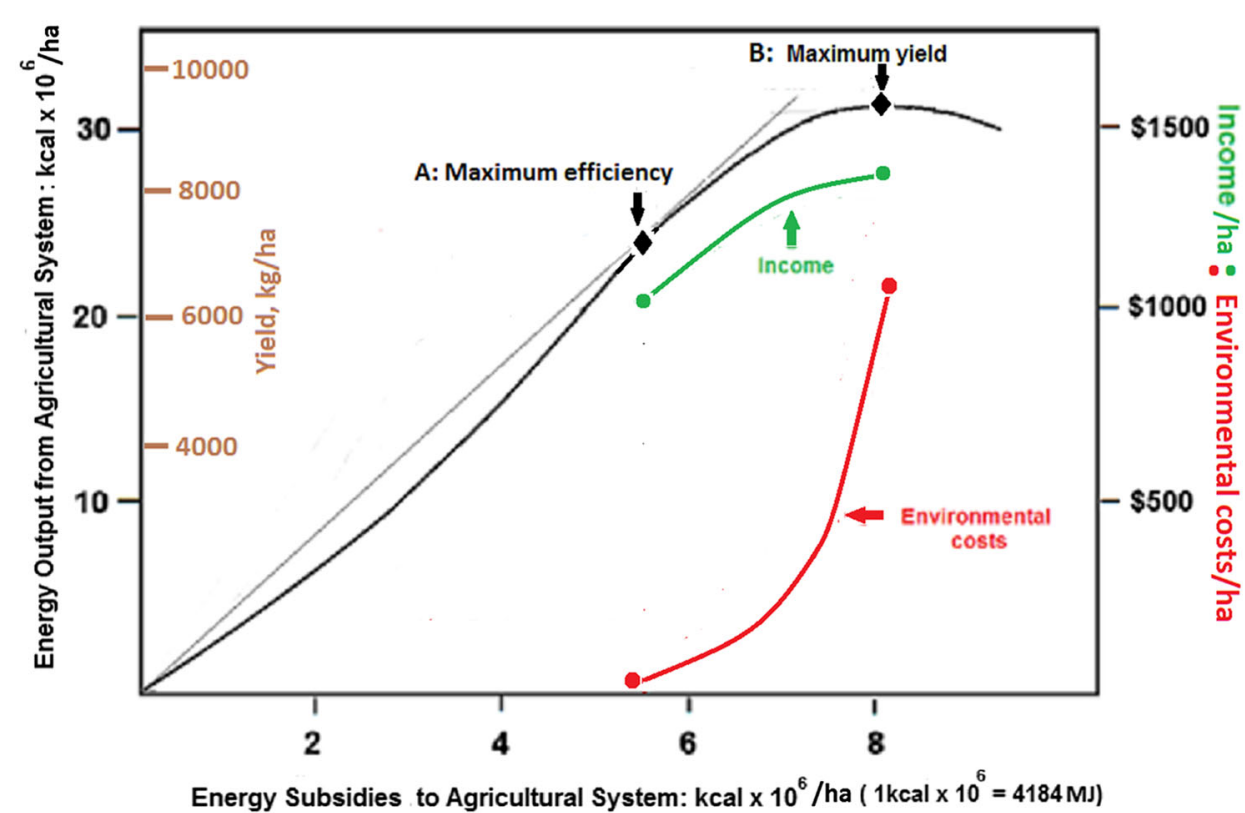


organic corn with conventional corn and found the ratio was 0.69 . Sixty-nine percent of input at point B is $5.6 \times 10^{6} \mathrm{kcal} /$ ha. The energy use efficiency at point $A$ then would be 4.45 .

\section{Economic Considerations}

\section{Income}

Income (green line) under point B was calculated as follows: Corn yield (from Pimentel and Pimentel 2008) was $8655 \mathrm{~kg} / \mathrm{ha}$, equivalent to $19,041 \mathrm{lb}$, equivalent to 340 bushels. Income per ha from 340 bushels $(8655 \mathrm{~kg})$ at the US price of $\$ 4.00$ per bushel is $\$ 1360$. Since yield under point $\mathrm{A}$ is $80 \%$ of point $\mathrm{B}$, income under point $\mathrm{A}$ was assumed to be $80 \%$ of that at point B or $\$ 1088$.

\section{Costs}

There are two kinds of economic costs in a farming system: external and internal.

- Internal costs are those of exosomatic energy inputs and are paid for by the farmer. They are the energy subsidies of the horizontal axis in Fig. 3. Internal costs are operating costs and include supplies such as chemicals, fuel, and seeds, as well as labor. Internal costs for the farmer also include capital costs such as for land, machinery, and buildings amortized over the life of the farm, but these are not included in EROI analyses because they are not energy subsidies that directly affect yield.

- External costs are costs for the environment and society (environmental costs, red line in Fig. 3) caused by the farming system and paid for by the public. The cost of removing nitrate (Table 4) represents only a portion of the total environmental cost of energy pollution, but in the absence of other data, it was used to depict the trajectory of the cost curve. At point A, the point of maximum energy use efficiency, cost was calculated by taking the point where energy efficiency is greatest (112 kg of $\mathrm{N}$ added/ha from Table 2) and cost of $\mathrm{N}$ pollution per ha at that point from Table $3(\$ 0 / \mathrm{ha})$. Environmental costs from nitrogen pollution for energy-intensive farms operating at maximum yield (point B) were calculated by taking the point where yield is greatest $(201.6 \mathrm{~kg} / \mathrm{ha}$ from Table 2) and cost per hectare at that point from Table $3(\$ 1013.42 / \mathrm{ha})$.

\section{Profit}

Profit is income minus costs, but accounting for profit is problematic because certain costs such as for farm machinery depend on an arbitrary depreciation rate. If we assume that profits are directly proportional to income, a profit curve would parallel the income curve. A choice of inputs at point B would give the farmer the greatest profits. The optimum compromise between profits for the farmer and pollution reduction would occur at an input where the vertical distance between the red and green lines is maximum. This point depends on the trajectory of the income and environmental cost lines.

\section{A Farmer's Dilemma}

The economic values for income and environmental cost in Fig. 3 represent only one set of many possible values. Income to a farmer in the USA depends on the price of a bushel of corn which can vary year to year, month to month, or day to day. Losses to society from costs of environmental cleanup could vary depending on the type of pollution cleanup used. However, biophysical costs and yields are independent of economic fluctuations, and the energy production function resulting from these costs and yields will always follow the Maximum Power Principle as applied to agriculture: Farmers can maximize yields or maximize energy use efficiency, but they cannot do both at the same time. Maximum yield will always provide the greatest income to the farmer. Maximum efficiency will always result in the least pollution per unit output. Point A would be the most beneficial long-term economic choice for society and the environment. It would be a farmer's choice if he envisioned himself as part of the environment in which the farm was embedded. However, conventional economics prevent the industrial farmer from taking this holistic viewpoint. Most industrial farmers and corporate farms will maximize yields because to stay in business, they need to compete for market share. Odum and Pinkerton (1955) concluded, "In a surprising sort of way, this (the Maximum Power Principle) seems to be a statement favoring the survival of the spendthrift."

\section{The Ratchet Effect}

The ratchet effect is a situation or process that is perceived to be deteriorating or changing steadily in a series of irreversible steps. The implication is that there is a limit to which the ratchet can be tightened before a tragedy occurs. A ratchet effect in agriculture results from technology that increases yield. (Jordan 1998). If new agricultural technologies dependent on increased energy input result in yield surpassing the current maximum possible, an early adopter farmer will employ them. To keep competitive, other farmers will soon adopt these technologies, and energy input rates to cropland will increase. Increased yield 
will result in more food availability, so world hunger will be lessened, but world population will grow. Because of the larger population that depends on increased yield, the technologies that permitted the yield increase cannot be abandoned. The ratchet has tightened. The outcome is that there will be an increased impact on the farmland supporting this increased yield, and as yield for all farms increases, there will be a decrease in individual farm profits due to increased supply and resultant competition in the marketplace. The introduction of hybrid corn in Midwestern USA exemplifies this sequence. The increase in yield by early adopters required an increase in fertilization rates that increased leaching rates. When late adopters employed hybrids, the greater supply of corn lowered prices and profits decreased, while nitrogen pollution increased. To overcome low profits, farmers seek further technological fixes that will increase yield. Thus, problems of nutrient pollution in the Gulf of Mexico persist. Similar dynamics have occurred in the Baltic Sea, the Adriatic Sea, and the Black Sea (Mitcsh et al. 2001). The Green Revolution in India has had similar consequences for that country's soil and water resources (Pingali 2012).

\section{Can the Dilemma be Resolved?}

Are there approaches that can maintain or increase yield while reducing pollution? One might be increasing the energy use efficiency of exosomatic inputs.

\section{Increasing Efficiency of Exosomatic Energy}

\section{Genetic Engineering}

Fresco (2016) summarizes the case that genetic engineering can improve yields by providing plants with resistance to pests, disease, and weeds that decrease yield through appropriation of energy otherwise used for production of food for humans. Since less pesticide energy is required by plants genetically modified for such resistance, pollution is reduced. However, there is a question of energy allocation by the plant. Since the origins of agriculture, farmers and plant breeders have been altering energy allocation of wild species by cultivating them so they produce a higher yield of food and fiber for humans at the expense of defense and competitive ability. As a result, pesticides and fertilizers (exosomatic energy inputs) were required to combat insect pests and weeds. Genetic engineers are now introducing genes into crops that will protect them from insects and increase competitive ability, thereby decreasing reliance on agricultural chemicals. They are reversing the plant breeding that sacrificed natural protection from insects and weeds for increased yield. Is reversal possible without reducing yield? From a theoretical perspective, the first law of thermodynamics says no (Jordan 2002).

From an empirical standpoint, the question has not been definitively answered. A cropping practices survey published by the Leopold Center at Iowa State University (Duffy 1999) found that "Use of genetically-modified seed didn't appear to impact a farmer's bottom line for either corn or soybean production." If there is a reversal to protect against only one particular threat, the loss in yield might be small, because not all crop defenses have been traded for yield. For example, a genetically modified crop protected against insects by Bacillus thuringiensis would still need yield trade-offs to gain protection against weeds, disease, nutrient scarcity, and drought before it can survive without subsidies.

\section{Precision Agriculture}

Precision agriculture increases the efficiency of fertilizer use. A computer system in a tractor takes satellite data that indicate which parts of a field need more fertilizer and which parts need less. The computer then controls the rate of fertilizer application by the spreader behind the tractor. Instead of a uniform application of fertilizer over an entire field, more is applied where soil is poor, and less is applied where soil is rich. Fertilizer is distributed more economically. Technologies such as precision agriculture incrementally increase the efficiency of fertilizer use. However, they do not change the strategy of relying on exosomatic energy to facilitate increases in yield, a strategy that serves only to tighten the ratchet.

\section{Integrated Pest Management}

Integrated pest management (IPM) relies on monitoring of pest populations and applying synthetic chemical controls when economic damage exceeds the cost of controls. IPM increases the efficiency with which pesticides, fungicides, and herbicides are used, but like precision agriculture, it is still part of the industrial agriculture model that relies on exosomatic energy inputs. The objective still is to control nature.

\section{Increasing Efficiency Through Use of Endosomatic Energy}

Another approach that can maintain or increase yield while reducing pollution is through increasing the capacity of the system to use endosomatic energy by increasing energy stores that support the services of nature (Table 1). Services of nature such as nutrient recycling by the community of soil organisms are powered by carbon compounds, the products of photosynthesis. When part of the photosynthate 
of a system is funneled into producing organic matter to energize the soil community or to energize beneficial insects, less exosomatic energy will be needed for production of economic yield.

\section{Organic Agriculture}

Organic agriculture depends primarily on endosomatic energy inputs, including carbon compounds that feed pollinators, beneficial insects, and the community of soil organisms. Organic agriculture is often considered lowinput, high-efficiency agriculture, but this is not always the case (Schramski et al. 2013). The following studies were specifically designed to compare yield and energy use efficiency between conventional agriculture and organic agriculture managed for high energy use efficiency.

- Mäder et al. (2002) compared organic and conventional (industrial) farmed plots over a period of 21 years. They found that while crop yields were $20 \%$ lower in the organic trials, fertilizer and energy inputs were up to $53 \%$ lower, and pesticide input was reduced by $97 \%$. This means that while income from the organic fields was lower, profit may have been higher.

- Refsgaard et al. (1998) compared energy use in small grains, grass-clover, and fodder beets growing in organic and conventional Danish dairy farms. Conventional crop yields were higher, but they also used more energy subsidies, especially fertilizers. The conventional yields were not sufficiently higher to compensate for the extra use of energy compared with the organic crops. The authors suggested that better energy utilization in grain crops might be found at intermediate levels of fertilizer use.

- In another study of Danish agriculture, Dalgaard et al. (2001) found that for eight conventional and organic crop types, energy use was lower in the organic than in the conventional system, but yields were also lower. Conventional crop production had the highest energy production, whereas organic crop production had the highest energy efficiency.

- In a 10-year study of yield of coffee beans as a function of various long-term management strategies in Costa Rica, Rossi et al. (2011) and Virginio et al. (2015) found that agroforestry systems managed organically had lower yields but higher energy use efficiencies than coffee grown in open sun with intensive chemical fertilization. The higher market price for coffee that is certified "sustainably grown" may compensate for the lower yield.

Even when studies are not restricted to those having low-input, organic agriculture still generally has lower yields than conventional. de Ponti et al. (2012) compiled and analyzed a meta-dataset of 362 published organicconventional comparative crop yields. Results showed that organic yields of individual crops were on average $80 \%$ of conventional yields, but variation was substantial. Another analysis of 316 published studies comparing organic and conventional crops showed that on the average, organic yields were $25 \%$ lower than yields from conventional agriculture (Seufert et al. 2012). However, research at Rodale farms in Kutztown, Pennsylvania, has shown that over a period of 20 years, organic cultivation can match the yield of conventional cropping (Seidel et al. 2015). It may take decades for the soil organic matter in organic agriculture to build up to a point where organic yields can match those of conventional yields, and few organic-conventional comparisons have been done for that length of time.

\section{No-Till Agriculture}

In no-till agriculture, seeds are planted directly through the flattened residue of a cover crop. There is no mechanical disturbance of the soil. In strip till, narrow bands of mineral soil are opened up in a cover crop to facilitate planting of seeds. These techniques are sometimes called conservation tillage. Research at the Kellogg Biological Station's LongTerm (1989-2007) Ecological Research Program in Michigan (Snapp et al. 2015) compared no-till cropping systems with three other management strategies for a cornsoybean-winter wheat rotation: (1) The conventional system used fertilizer and herbicide inputs, and conventional tillage; (2) the no-till system used conventional management adapted for permanent no-till soil management; (3) the reduced input system used biologically based management, including winter cover crops, to reduce synthetic chemical inputs to one-third of those used in the conventional system; and (4) the biologically based system used clover and rye to entirely substitute for synthetic chemical inputs. No systems received manure or compost. The reduced input and biologically based systems included cover crops of red clover inter-seeded in wheat in the spring and annual rye planted after corn harvest in the fall. The biologically based system simulates organic management practices and is USDA-certified organic.

Compared to the other systems, the no-till cropping system had not only higher yield (Table 5) but also higher energy use efficiency (Fig. 4).

\section{No-Till as a Mimic of Ecological Succession}

Schneider and Kay (1994) pointed out that a thermodynamic interpretation of ecological succession would predict that natural ecosystems develop toward maximum biomass, maximum endosomatic throughput, high efficiency, and 
Table 5 Average annual grain crop yields, soil carbon gains, and nitrate leaching loss over the period 1989-2007. Data from Table 15.3 in Snapp et al. (2015)

\begin{tabular}{llcl}
\hline Management & $\begin{array}{l}\text { Crop yield } \\
\left(\mathrm{Mg} \mathrm{ha}^{-1} \text { year }^{-1}\right)\end{array}$ & $\begin{array}{l}\text { Soil C gain }(\mathrm{kg} \\
\left.\mathrm{C} \mathrm{ha}^{-1} \text { year }^{-1}\right)\end{array}$ & $\begin{array}{l}\text { Nitrate } \\
\text { leaching loss } \\
\left(\mathrm{kg} \mathrm{NO}_{3}^{-}\right. \\
\left.\mathrm{N} \mathrm{ha}^{-1} \text { year }^{-1}\right)\end{array}$ \\
\hline $\begin{array}{l}\text { Conventional } \\
\text { No-till }\end{array}$ & 3.5 & 0 & 62 \\
$\begin{array}{l}\text { Reduced } \\
\text { input }\end{array}$ & 3.9 & 330 & 42 \\
$\begin{array}{l}\text { Biologically } \\
\text { based }\end{array}$ & 2.8 & 200 & 24 \\
\hline
\end{tabular}

maximum stability. An important characteristic of terrestrial ecological succession is increase in soil organic matter (stored energy). Recycling of nutrients by microorganisms feeding on soil organic matter increases plant growth. Increased growth in turn provides increased detritus, and this provides more energy for the microorganisms that increase nutrient recycling efficiency even further. No-till agriculture mimics natural succession in that there is a buildup of soil organic matter. Formation of soil aggregates in no-till protects the carbon from oxidation and loss that would occur due to plowing and rototilling the soil during conventional and organic agriculture (Paul et al. 2015). Thus, in a farm employing no-till cultivation, there are autocatalytic thermodynamic systems at two hierarchical levels. One is at the farm level, where income dollars from the sale of economic energy output (yield) stimulates investment dollars that maintains the farm clear of weeds and pests. The other is at the field level where the autocatalytic feedback is energy from decomposing detritus that stimulates nutrient recycling (Fig. 5).

\section{No-Till Agriculture and the Maximum Power Principle}

Odum and Pinkerton (1955) pointed out that a characteristic of living organisms is an autocatalytic feedback system in which some of the energy from catabolism of energy compounds is used to drive an anabolic system. This coupling results in growth, reproduction, and maintenance. Ecosystems also can demonstrate autocatalysis. In the notill cropping ecosystem, it is the feedback of endosomatic energy from the soil community that allows development of the system to a state of higher efficiency and yield. Because of the endosomatic feedback, the no-till system had a more stable environment for soil organisms, and there was better soil water infiltration, water-holding capacity, and higher yield (Snapp et al. 2015). No-till develops an autocatalytic feedback system dependent on soil organic matter derived from products of photosynthesis (Fig. 5).
Fig. 4 Energy use efficiency as a function of exosomatic energy input. Values from Table 15.2 in Snapp et al. (2015)

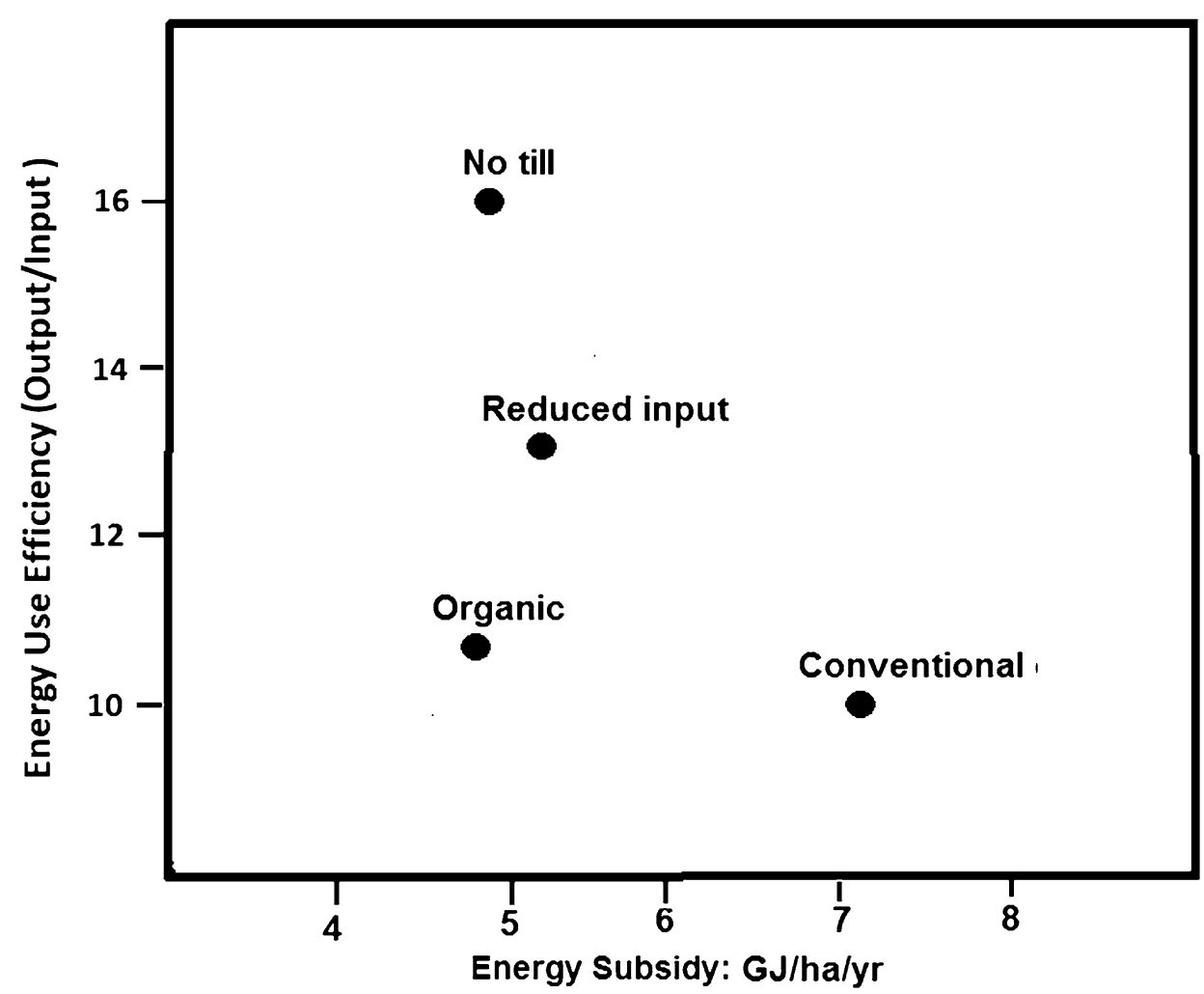


Fig. 5 Energy and dollar flows in a no-till farming system and the crop-soil sub-system. Sunlight is radiant energy; yield is energy embedded in the economic crop; endosomatic energy is energy embedded in detritus; and yield energy is converted to dollars that buys additional exosomatic energy

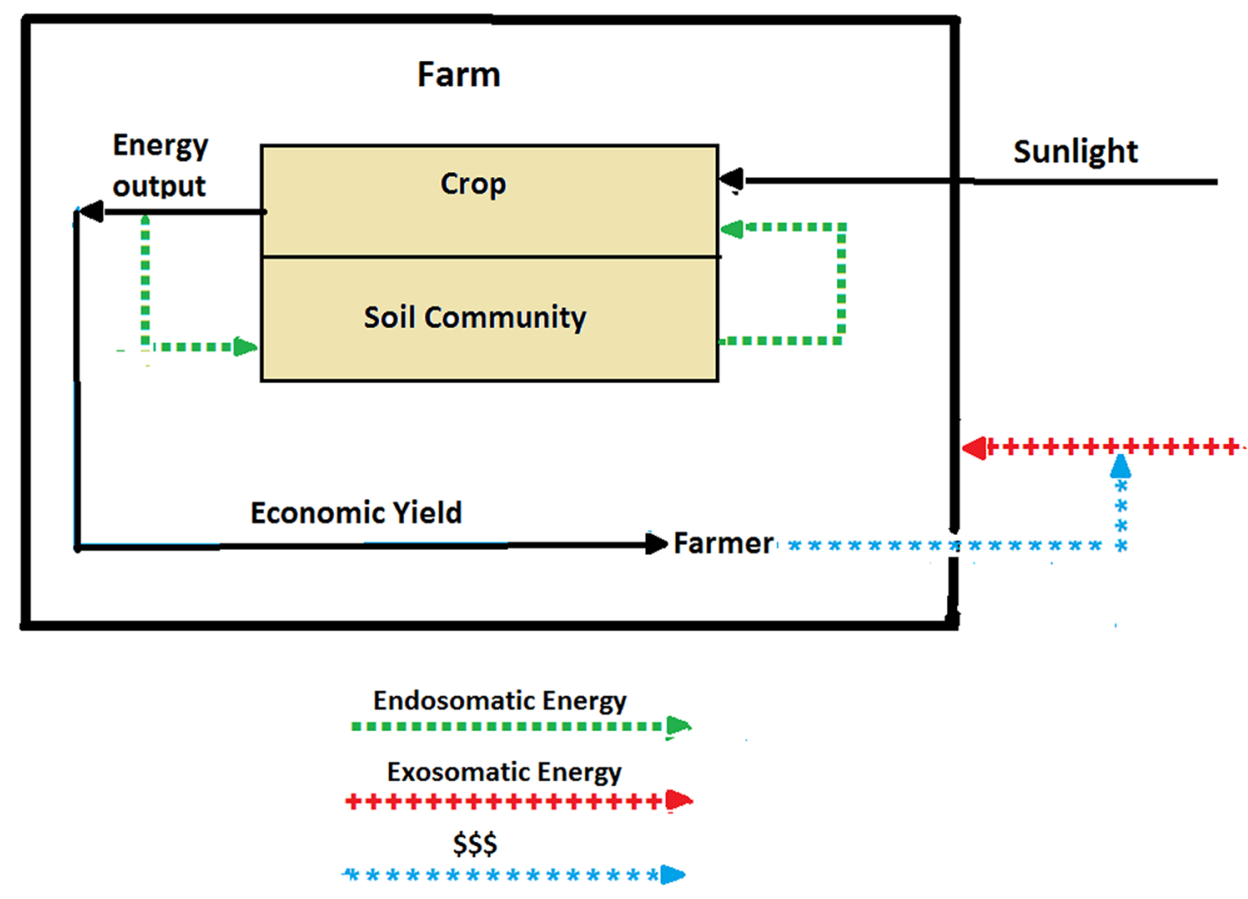

\section{Organic Versus No-Till Farming}

Development of the soil system in no-till at the Kellogg research station suggests that increases in endosomatic feedback loops through incorporation of plant residue in the soil can increase exosomatic (farm level) energy use efficiency and decrease environmental pollution. Since organic agriculture relies on endosomatic inputs for crop fertilization, why is the energy use efficiency of the organic system in Fig. 4 so low? Mechanical cultivation, permitted in organic agriculture, destroys the soil organic matter through oxidation by soil bacteria when the soil is disturbed and autocatalytic feedback is disrupted. In contrast, no-till not only conserves the feedback loop, it increases soil carbon as the stalks, leaves, and roots of the cover crop decompose and provide an energy source for the community of soil organisms. However, no-till is forbidden in organic agriculture because it requires the use of herbicides to control weeds that emerge through the flattened cover crop.

\section{Energy Savings Through No-Till Agriculture}

A comparison of energy costs of weed control in soybeans by mechanical tillage and by herbicide treatment published by Extension (2016) indicated that costs were similarapproximately $143,254 \mathrm{kcal} / \mathrm{ha}$. Estimates included both manufacturing costs and application costs of herbicides. However, the study did not consider the energy losses incurred when soil organic matter is oxidized or eroded by mechanical tillage. Energy stored in the soil organic matter of a pre-colonial forest ecosystem in southern USA amounted to $940\left(10^{6}\right) \mathrm{kcal} / \mathrm{ha}$ (Jordan2013). It took approximately 100 years for cotton farming to deplete this natural capital. Thus, energy loss due to mechanical tillage must have averaged $940\left(10^{4}\right) \mathrm{kcal} / \mathrm{ha} / \mathrm{year}$. This figure could indicate the magnitude of energy savings in the southeastern USA through the use of cultivation that does not destroy soil organic matter.

\section{Conclusions}

The objectives of this paper were:

- To show that a farm as a thermodynamic system is subject to the Maximum Power Principle and that this principle can explain why agricultural problems have been so intractable. Conclusion Because a farm consists of inputs and outputs both of which have energy equivalents, a farm can be considered a thermodynamic system and thus is subject to the Maximum Power Principle. The principle suggests that management for maximum yield has high environmental costs, while management for energy use efficiency minimizes pollution. Regardless, most farmers will maximize yield to obtain a competitive advantage in the marketplace, thus perpetuating the problem of agricultural pollution.

- To show how management that increases endosomatic feedback loops can increase exosomatic energy use efficiency and decrease environmental pollution. 
Conclusion Comparisons of organic with conventional farms have shown that managing for high energy use efficiency results in lower yields but lower environmental impact. However, studies at the Kellogg station in Michigan have shown that a no-till system relying on an autocatalytic feedback system based on activity of soil microorganisms increased both yield and exosomatic energy use efficiency. Feedback loops dependent on the services of nature may be the key to an environmentally sustainable agriculture.

\section{References}

Allen TFH, Giampietro M, Little AM (2003) Distinguishing ecological engineering from environmental engineering. Ecol Eng 20:389-407

Baca B, Florey S, King D, Bohlen C (2016) Economic analysis of wetlands mitigation projects in the southeastern U.S. http:// images.library.wisc.edu/EcoNatRes/EFacs/Wetlands/Wetlands21/ reference/econatres.wetlands21.bbaca.pdf. Accessed 13 July 2016

Black JN (1971) Energy relations in crop production-a preliminary survey. Ann Appl Biol 67:272-278

Breitburg DL, Hondorp DW, Davias LA, Diaz RJ (2009) Hypoxia, nitrogen, and fisheries: integrating effects across local and global landscapes. Annu Rev Mar Sci 1:329-349

Carson R (1962) Silent spring. Houghton Mifflin, Boston

Colorado State (2016) Constructed wetlands. http://rydberg.biology. colostate.edu/phytoremediation/2006/Rebecca\%20Newton $\% 20$ Website\%20Files/public_html/CW.html. Accessed 13 July 2016

Cox GW, Atkins MD (1979) Agricultural ecology. Macmillan, London

Daily GC et al (1997) Ecosystem services: benefits suplied to human societies by natural ecosystems. Issues in ecology no. 2 (Spring). Ecological Society of America, Washington, DC

Dalgaard T, Halberg N, Porter JR (2001) A model for fossil energy use in Danish agriculture used to compare organic and conventional farming. Agric Ecosyst Environ 87:51-65

de Ponti T, Rijk B, van Ittersum MK (2012) The crop yield gap between organic and conventional agriculture. Agric Syst 108:1-9

Deberton DL (2012) Agricultural production economics. University of Kentucky, Department of Agricultural Economics. http:// www.uky.edu/ deberti/prod/agprod5.pdf. Accessed 13 July 2016

Department of Environmental Quality (2016) Nitrate in drinking water. http://www.deq.state.or.us/wq/pubs/factsheets/ground water/nitratedw.pdf. Accessed 13 July 2016

Duffy, M. (1999) Does planting GMO seed boost farmers' profits? https://www.leopold.iastate.edu/news/leopold-letter/1999/fall/doesplanting-gmo-seed-boost-farmers-profits. Accessed 13 July 2016

EPA (2015a) Mississippi River/Gulf of Mexico watershed nutrient task force. 2015 report to congress. http://www2.coastalscience. noaa.gov/publications/detail.aspx?resource $=I T s K 3 \mathrm{r} 0 \mathrm{bfy} 0 \mathrm{kbAb}+$ Mi3dQXRs8kKN9U0r5lpDq0enTD0=. Accessed 13 July 2016

EPA (2015b). Basic information about nitrate in drinking water. http://water.epa.gov/drink/contaminants/basicinformation/nitrate. cfm. Accessed 13 July 2016
Extension (2016) Energy use and efficiency in pest control, including pesticide production, use, and management options. https:// articles.extension.org/pages/62513/energy-use-and-efficiency-inpest-control-including-pesticide-production-use-and-managementoptions. Accessed 13 July 2016

Fluck RC, Baird CD (1980) Agricultural energetics. AVI Publishing, Westport

Fresco LO (2016) Hamburgers in paradise. Princeton University Press, Princeton

Galloway JN, Townsend AR, Erisman JW, Bekunda M, Zucong C, Freney JR, Martinelli LA, Seitzinger SP, Sutton MA (2008) Transformation of the nitrogen cycle: recent trends, questions, and potential solutions. Science 320:889-892

Gelfand I, Snapp SS, Robertson GP (2010) Energy efficiency of conventional, organic, and alternative cropping systems for food and fuel at a site in the US Midwest. Environ Sci Technol 44:4004-4011

Giampietro M (1997) Socioeconomic constraints to farming with biodiversity. Agric Ecosyst Environ 62:145-167

Giampietro M (2004) Multi-scale integrated analysis of agroecosystems. CRC Press, Boca Raton

Jensen VB, Darby JL, Seidel C, Gorman C (2012) Drinking water treatment for nitrate. In: Center for watershed sciences, University of California, Davis. Technical report 6. Report for the state resources control board. Report to the legislature. Addressing nitrate in California's drinking water with a focus on Tulare Lake Basin and Salinas Valley groundwater. http://groundwater nitrate.ucdavis.edu. Accessed 14 July 2016

Jordan CF (1998) Working with nature: resource management for sustainability. Harwood Academic Publishers, Australia

Jordan CF (2002) Genetic engineering, the farm crisis, and world hunger. Bioscience 52:523-529

Jordan C (2013) An ecosystem approach to sustainable agriculture: energy use efficiency in the American South. Springer, Dordrecht

Kerr RA (2008) World oil crunch looming? Science 322:1178-1179

Little JB (2009) The ogallala aquifer: saving a vital US water source. http://www.scientificamerican.com/article/the-ogallala-aquifer/. Accessed 14 July 2016

Lobao L, Stofferhan CW (2007) The community effects of industrialized farming: social science research and challenges to corporate farming laws. Agric Hum Values. doi:10.1007/ s10460-007-9107-8

Lotka AJ (1922a) Contribution to the energetics of evolution. Proc Natl Acad Sci 8(6):147-151

Lotka AJ (1922b) Natural selection as a physical principle. Proc Natl Acad Sci 8(6):151-155

Mäder P, Fließbach A, Dubois D, Gunst L, Fried P, Niggli U (2002) Soil fertility and biodiversity in organic farming. Science 296:1694-1697

Mallin MA (2000) Impacts of industrial animal production on rivers and estuaries. Am Sci 88:26-37

McNeill JR, Winiwarter V (2004) Breaking the sod: humankind, history, and soil. Science 304:1627-1629

Mitcsh WJ, Day J, Gilliam JW, Groffman PM, Hey DL, Randall GW, Wang N (2001) Reducing nitrogen loading to the Gulf of Mexico from the Mississippi River Basin: strategies to counter a persistent ecological problem. Bioscience 51:373-388

Mlot C (2000) Antidotes for antibiotic use on the farm. Bioscience 50:955-960

Murphy DJ, Hall CAS (2010) Year in review-EROI or energy return on (energy) invested. Ann N Y Acad Sci 1185:102-118

Odum HT (1995) Self-organization and maximum empower. In: Hall CAS (ed) Maximum power: the ideas and applications of $\mathrm{H}$. T. Odum. Colorado Univ. Press, Boulder, pp 311-330 
Odum HT, Odum EC (1981) Energy basis for man and nature. McGraw-Hill, New York

Odum HT, Pinkerton RC (1955) Time's speed regulator: the optimum efficiency for maximum power output in physical and biological systems. Am Sci 43:331-343

Odum EP, Finn JT, Franz EH (1979) Perturbation theory and the subsidy-stress gradient. Bioscience 29:349-352

Paul EA, Kravchenko A, Grandy AS, Morris S (2015) Soil organic matter dynamics: controls and management for sustainable ecosystem function. In: Hamilton SK, Doll JE, Robertson GP (eds) The ecology of agricultural landscapes: long term research on the path to sustainability. Oxford Univ. Press, New York, pp 104-134

Pimentel D (2006) Impacts of organic farming on the efficiency of energy use in agriculture. An organic center state of science review. https://www.organic-center.org/reportfiles/ENERGY SSR.pdf. Accessed 14 July 2016

Pimentel D, Pimentel MH (2008) Food, energy and society, 3rd edn. CRC Press, Boca Raton

Pingali PL (2012) Green revolution: impacts, limits, and the path ahead. Proc Natl Acad Sci 109(31):12302-12308

Real LA (1996) Sustainability and the ecology of infectious disease. Bioscience 46:88-97

Refsgaard K, Halberg N, Kristensen ES (1998) Energy utilization in crop and dairy production in organic and conventional livestock production systems. Agric Syst 57:599-630

Rossi E, Montagnini F, de Melo Virginio Filho D (2011) Effects of management practices on coffee productivity and herbaceous species diversity in agroforestry systems in Costa Rica. In: Montagnini F, Francesconi W, Rossi E (eds) Agroforestry as a tool for landscape restoration. Nova Science Publishers, New York, pp 115-132

Schneider ED, Kay JJ (1994) Life as a manifestation of the second law of thermodynamics. Math Comput Model 19:25-48

Schramski JR, Jacobsen KL, Smith TW, Williams MA, Thompson TM (2013) Energy as a potential systems-level indicator of sustainability in organic agriculture: case study model of a diversified, organic vegetable production system. Ecol Model 267:102-114
Seidel R, Moyer J, Nichols K, Bhosekar V (2015) Studies on longterm performance of organic and conventional cropping systems in Pennsylvania. Organ Agric. doi:10.1007/s13165-015-0145-z

Service RF (2007) A growing threat down on the farm. Science 316:1114-1117

Seufert V, Ramankutty N, Foley JA (2012) Comparing yields of organic and conventional agriculture. Nature 485:229-232

Smathers WM, Jordan CF, Farnworth EG, Tidrick TH (1983) An economic production function approach to ecosystem management. Bioscience 33:642-646

Snapp SS, Smith RG, Robertson GP (2015) Designing cropping systems for ecosystem services. In: Hamilton SK, Doll JE, Robertson GP (eds) The ecology of agricultural landscapes: long term research on the path to sustainability. Oxford Univ. Press, New York, pp 378-408

Soule JD, Piper JK (1992) Ecological crises of modern agriculture. In: Soule JD, Piper JK (eds) Farming in nature's image. Island Press, Washington, pp 11-50

Steinhart CE, Steinhart JS (1974) Energy sources, use, and role in human affairs. Duxbury Press, North Scituate

Striffler S (2005) Chicken: the dangerous transformation of America's favorite food. Yale Agrarian Studies Series, New Haven

Then C (2000) A danger to the world's food; genetic engineering and the economic interests of the life-science industry. In: Qaim M, Krittiger A, Qaim M (eds) Agricultural biotechnology in developing countries: towards optimizing the benefits for the poor. Kluwer, Boston, pp 229-236

Virginio FE et al (2015) La Productividad Útil, la Materia Orgánica y el Suelo en los Primeros 10 Años de Eda den Sistemas de Priducción de Café a Pleno sol y Bajo Vaios Tipos de Sombra y Niveles de Insumos Orgaánicos y Convencionales en Costa Rica In: Montagnini, F, Somarriba E, Murgueito E, Fassola H, Eibl, B. Sistemas Agroforestales: Funciones Productivas, Socioeconómicas y Ambientales. Serie técnica. Informe técnico 402. CATIE, Turrialba, Costa Rica. Editorial CIPAV, Cali, Colombia, pp 131-151 